\title{
Comparison of IAA Production by Shallot Rhizosphere Isolated Bacteria in Solid and Liquid Media and Their Effect on Shallot Plant Growth
}

Kafrawi $^{1^{\star}}$, Nildayanti ${ }^{1}$, Zahraeni $\mathrm{K}^{1}$ and Baharuddin ${ }^{2}$

${ }^{1}$ Pangkep State Polytechnic of Agriculture, Pangkep, 90655, Indonesia

${ }^{2}$ Hasanuddin University, Makassar, 90245, Indonesia

\begin{abstract}
Some of free-living rhizobacteria were isolated from rhizosphereof shallot growing in two different fields on Sulawesi Island. The bacterial isolates were cultured in liquid and solid media and were further tested for their ability to produce bioauxin. L-Tryptophan as a physiological precursor of auxin was added to the culture media and the production of IAA was tested using a colorimeter method. Six isolates from west Sulawesi and ten isolates from South Sulawesi were found to produce bioauxin, while 40 other isolates had negative results on IAA production. The amount of IAA produced by the isolates on liquid medium ranged from 4.01 to $8.62 \mathrm{ppm}$, while in the solid medium, the concentration of IAA produced by the same bacteria was considerably lower than in Liquid media. Thus, culture conditions influence the secretion of IAA by the bacteria. Of these 16 IAA producing isolates, five efficient producers were used for in plant a growth promotion assay. The isolate MK6-1-1 showed the best stimulatory effect on leaves number and bulb tillers, isolate LB8 was investigated to modulate better bulbs fresh biomass weight, while isolate MK11 was found to have the best effect on bulbs dry weight and bulbs dry biomass weight. Application of liquid media MK 6-1-1 bacteria isolates on the medium shallot planting early phases provides the best results on the vegetative growth of shallot that is leafs number ( 10.75 pieces) and the number of bulb tillers ( 2.75 bulbs) except the best plants height showed by Isolate bacteria MK $11(29,60 \mathrm{~cm})$. Bacterial isolates LB 8 shows bulbs fresh biomass weight $(9.83 \mathrm{~g})$ and bulbs fresh biomass shrinkage $(7.45)$ while the bacteria Isolate MK 11 showed the best result of bulb dry weight $(2.26 \mathrm{~g})$ and bulbs dry biomass weight (3.41).
\end{abstract}

Keywords: Rhizobacteria; Shallot; Indole acetic acid; Sulawesi

\section{Introduction}

Shallot (Allium ascalonicum) is a vegetable that is important in tropical regions like Indonesia and Brazil because it is almost always needed by household consumers as a complement for everyday spice, and besides, shallot is also used as a medicine. Therefore, the availability of shallot commodity is always made sure by balancing its production increase and population increase.

A certain chemical compound is commonly added to a plant in order to promote the plant growth and production. Auxin (IAA) is a phytohormone compound frequently found to be a limiting factor of plant growth and addition of synthetic auxin has become a common practice in modern agriculture. Indole Acetic Acid (IAA) is the main hormone in plants to control various important physiological processes including cell growth and mutation, tissue differentiation and response toward light and gravitation [1].

The use of synthetic chemical has given many negative impacts in the form of environmental pollution. The awareness of environment and health and the growth of biotechnology have encouraged the development of the utilization of natural materials in the practices of plant culture including the use of soil bacterial micro-organisms.

Rhizobacteria can support plant growth directly, for example by producing growth regulating substance. The growth regulating substances produced include IAA, gibberellin, cytokinin and ethylene [2]. The bacteria that can produce auxin includes Pseudomonas sp., Azospirillium sp., Azotobacter sp., Bacillus sp., Lactobacillus sp., Paenibacillus polymyxa, Enterobacter sp., Serratia marcescens, Klebsiella sp., Alcaligenes faecalis and Cyanobacteria $[1,3]$.

El-Mahrouk and Belal, stated that on a laboratory scale, Azotobacter auxin production increase occurs with the addition of tryptophan on supernatant of water culture [4]. Tryptophan is an auxin inducer provided by plants for auxin-producing bacteria in a natural condition.
Biosynthesis of auxin by microbe in the soil increases in the presence of L-tryptophan originating from exudate of root or broken organism cells, because L-tryptophan is a precursor in the path of auxin biosynthesis [5].

Patten and Glick explained that plants probably do not synthesize auxin in a sufficient amount for optimum growth [6]. Therefore, it is necessary to have addition of growth-promoting hormone from outside, although in many kinds of research that have been done the plant responses to auxin produced by microbe vary depending on plant species and the concentration of auxin released.

Aryantha et al. [7] stated that green bean sprouts grown hydroponically with water of actinomycetes groove LC (36.4 $\mu \mathrm{g}$ auxin/ $\mathrm{mL}$ media) and Bacillus groove D3 (52.5 g auxin/ $\mathrm{mL}$ media) can increase the number of lateral roots and length of sprouts in 20 times of thinning. Meanwhile, the culture of actinomycetes groove LC in 40 times and 60 times of thinning has affected to increase the optimum length of sprouts. The results fit the properties of effective growth hormone in a very small number. Raharjo stated that combination of Sulphur dosage and concentration of IAA highly really affects the height of plant and is found on S1I3, with an average height of $40.1 \mathrm{~cm}$ [8].

Kafrawi et al. succeeded in isolating some auxin-producing bacteria from rhizosfer of shallot agriculture in solid media (nutrient agar) [9].

*Corresponding author: Kafrawi, Pangkep State Polytechnic of Agriculture, Pangkep, 90655, Indonesia, Tel: 081342125497; Fax: +624102312705; E-mail: kafrawidjamin@gmail.com

Received September 27, 2017; Accepted October 30, 2017; Published October 31, 2017

Citation: Kafrawi, Nildayanti, Zahraeni K, Baharuddin (2017) Comparison of IAA Production by Shallot Rhizosphere Isolated Bacteria in Solid and Liquid Media and Their Effect on Shallot Plant Growth. J Microb Biochem Technol 9: 266-269. doi: 10.4172/1948-5948.1000375

Copyright: @ 2017 Kafrawi, et al. This is an open-access article distributed under the terms of the Creative Commons Attribution License, which permits unrestricted use, distribution, and reproduction in any medium, provided the original author and source are credited. 
Nevertheless, the auxin producing ability in liquid media is not yet known. This information becomes important because the giving of microbe to plants through soil is usually done in the form of liquid media while the effect of liquid media on the growth of shallot plant is also not yet known.

\section{Materials and Methods}

\section{Microbial isolation}

Soil samples were taken from the vicinity of the roots (rhizosphere) of healthy shallot plants grown in Malakaji (South Sulawesi) and Limboro (West Sulawesi). The soil samples were serially diluted and 5 $\mathrm{ml}$ of samples of solution were spread on Nutrient Agar (NA) medium and incubated at $28 \pm 2^{\circ} \mathrm{C}$ for $24 \mathrm{~h}$. Colonies showing prolific growth were selected and purified by streaking five times on fresh plate of NA. 56 bacterial isolates having different morphological appearance were stored in slants NA medium before used for measurement of auxin production as IAA equivalents [9].

\section{IAA production on solid media}

A collection of 56 bacterial isolates were previously screened for production of IAA production using the modified method as described by El-Mahrouk and Belal [4] and Zakry et al. [10]. The bacterial isolates were grown on nutrient agar (NA) medium supplemented with0.1g/L L-Tryptophan and incubated at $28 \pm 2^{\circ} \mathrm{C}$ for 3 days.

\section{Colorimetric analysis}

The bacterial isolates were assayed for production of IAA using the modified method developed by Loper and Scroth [11]. Bacterial colonies growing on nutrient agar as described above were harvested by pouring $5 \mathrm{ml}$ of distilled water and centrifuged at $3000 \mathrm{rpm}$ for $30 \mathrm{~min}$. The supernatant $(2 \mathrm{ml})$ was mixed with two drops of ortophosphoric acid and $4 \mathrm{ml}$ of Salkowski reagent $(50 \mathrm{ml}, 35 \%$ of sulphuric acid, $1 \mathrm{ml}$ $0.5 \mathrm{M} \mathrm{FeCl}_{3}$ ). The Development of a pink-colored in the culture filtrate after $24 \mathrm{~h}$ of incubation indicates the occurrence of IAA. Intensity of the color was measured on spectrophotometer at $530 \mathrm{~nm}$. Concentration of IAA produced by cultures was measured using standard graph of IAA (Sigma-Aldrich) obtained in the range of 0.5-10 ppm.

\section{IAA production on liquid media}

Out of 56 bacterial isolates, 16 were characterized as auxin producer bacterial isolates by using solid media. The amount of auxin quantity by 16 isolates potential were determined by orbital shaking bacterial cultures for 7 days at $28 \pm 2^{\circ} \mathrm{C}$ in nutrient broth media. The auxin content of the culture filtrate was in accordance with Loper and Scroth [11].

\section{Eficacy of auxin-producing bacteria}

The experiment was done in a screen house. The design used was Group Random Design with the treatment of the best 5 isolates added with control. Every treatment consisted of 4 repetitions and every repetition consisted of 2 units of experiment plants. So, there were 48 units of experiment plants. Parameter of observation covered: 1) vegetative growth of plant in the form of plant height, leaves number per plant, and bulb tillers number per plant observed at the age of 17 MST (12 days before harvest), 2) weight of fresh residual bulbs, namely total weight of bulbs, leaves, and root at harvest, 3 ) dry residual bulbs weight of shrinkage shallot, namely total weight of bulbs, leaves, and roots after dried in open air for 7 days since harvest, 4) loss of plant weight (residual bulbs) after dried in open air for 7 days, 5) weight of dry cleaned bulbs of shrinkage shallot, namely the weight of dry clean bulbs of askip shallot with no leaves and roots. Data were analyzed using prints of variety and differences between test treatments with the Least Significant Different (LSD) at the degree of probability $5 \%$.

\section{Results and Discussion}

\section{Comparison of auxin production media}

Quantitative measurement of growth is intended to find out various responses of microorganism growth in various media or in different conditions so they can be used in judging the supporting power of a certain medium to support growth [12]. Growth medium of bacteria must fulfill nutrition requirements needed by a microorganism [13]. The nutrition needed by a microorganism for its growth covers carbon, nitrogen, non-metal element such as sulphur and phosphor, metal elements such as $\mathrm{Ca}, \mathrm{Zn}, \mathrm{Na}, \mathrm{K}, \mathrm{Cu}, \mathrm{Mn}, \mathrm{Mg}$, and $\mathrm{Fe}$, vitamin, water and energy [14].

Among 16 isolates from rhizosphere of shallot, 10 isolates are isolated from Malakaji (South Sulawesi) and 6 isolates are isolated from Limboro (West Sulawesi). Result of colorimetric test of shallot isolates indicated that different isolates of rhizobacteria varied in their efficiency for producing auxins in the presence of L-tryptophan, both in solid and liquid media. Colorimetric analysis from isolates approximately showed the increase amount of auxins produced by culture of liquid media (ranging from $4.01 \mathrm{ppm}$ to $8.62 \mathrm{ppm}$ IAA-equivalents) better than solid media (ranging from 0.76 to 2.33 ppm IAA-e equivalents). Isolate MK 11 produced the highest amount of IAA $(8.62 \mathrm{ppm})$ while isolates MK 12-1 produced the lowest amount of IAA (4.01 ppm).

Like other organisms, in order to grow, bacteria need certain essential nutrition from their living place or medium. Essential nutrition is divided into two groups: the nutrient needed as energy supply to grow and the nutrient needed as chemical elements supply necessary for biosynthesis. From various forms of energy available, bacteria can use chemical energy and light to grow [15].

Solid media comes from liquid media where, in its making, materials are added so that after it becomes solid when it is already cold. Bacterial growth in solid media is only possible on the media surface, while in liquid media, bacteria can grow in the media so with abundant nutrition content in liquid media, the process of bacterial metabolism will happen optimally and the process of cell mutation runs well that can cause the size of colony becomes bigger. The big size of colony causes the amount of auxin production to increase in liquid media, compared to that in solid media.

Gandjar stated that the complex content in the media can cause the growth of microorganisms to need more time to break down simple components that can be absorbed by cells be used for syntheses of cells and energy [16]. In a good nutritional condition, the time needed for bacterial growth is relatively fast; on the contrary, if the nutrition needed is not abundant, cells must adapt with environment and the forming of enzymes to break down substrate needs more time [17] (Table 1 and Figure 1).

\section{Early shallot growth trial}

Indole acetic acid is a type of auxin essential for plant growth and development. IAA is involved in various plant physiological processes such as root initiation, cell elongation, vascular tissue differentiation and flowering [18].

Observation of the growth of shallot plant after given auxinproducing bacterial isolate on its planting media shows that all 
Citation: Kafrawi, Nildayanti, Zahraeni K, Baharuddin (2017) Comparison of IAA Production by Shallot Rhizosphere Isolated Bacteria in Solid and Liquid Media and Their Effect on Shallot Plant Growth. J Microb Biochem Technol 9: 266-269. doi: 10.4172/1948-5948.1000375

\begin{tabular}{|c|l|c|c|}
\hline \multirow{2}{*}{ Origin } & \multirow{2}{*}{ Isolate Code } & \multicolumn{2}{|c|}{ IAA Quantity (ppm) } \\
\cline { 3 - 4 } & & Solid Media [9] & Liquid Media \\
\hline South Sulawesi & MK2 & 1.53 & 5.34 \\
\hline & MK 5-1 & 1.14 & 5.21 \\
\hline & MK 6-1-1 & 2.20 & 6.10 \\
\hline & MK 8 & 1.03 & 5.48 \\
\hline & MK 11 & 2.33 & 8.62 \\
\hline & MK 12-1 & 0.76 & 4.01 \\
\hline & MK 13 & 1.21 & 5.71 \\
\hline & MK 13-1 & 1.38 & 5.35 \\
\hline & MK 15-2 & 1.46 & 5.38 \\
\hline & MK 22 & 1.46 & 5.41 \\
\hline West Sulawesi & LB1 & 1.22 & 5.47 \\
\hline & LB 3 & 2.14 & 7.76 \\
\hline & LB 4 & 1.20 & 5.43 \\
\hline & LB 5-2-1 & 1.71 & 5.62 \\
\hline & LB 8 & 1.97 & 5.03 \\
\hline & LB 11 & 1.66 & 5.54 \\
\hline
\end{tabular}

Table 1: Indole acetic acid concentration produced by rhizobacteria of shallot rhizospheres soil.
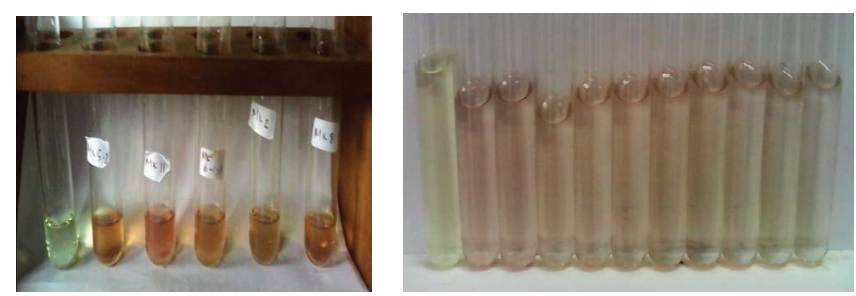

Figure 1: Samples of the pink color solution containing indole acetic acid.

parameters of observation have not-real effect, except for height of plant that has real effects (Table 2).

Least Significant Different (LSD) in Table 1 shows that the tallest plant was obtained from the treatment of isolate of bacteria MK11 and was really different from LB 8 and LB 4 but was not-really different from treatment MK 6-1-1 and LB 3 (Figures 2-4).

Sutariati reported that addition of growth hormone through the treatment of inoculation PGPR by using isolates Bacillus sp., Pseudomonas sp., and Serratia sp. by using the procedure of standard sprouting, significantly increases the viability of chili seedlings as much as $27 \%$, index vigor $(31 \%)$, growth spontaneity $(29 \%)$, relative rate of growth (29\%) and lessens the time needed for the sprouting until 0.75 day [19].

Explained further that the use of plant growth promoting rhizobacteria (PGPR) as bio-fertilizer is a biotechnological contribution in an effort to increase plant production. This thing is achieved by mobilizing nutrient, plant hormone production, nitrogen fixation, or the activation of mechanism of immune toward diseases [20,21].

The results of this experiment showed that the treatment of bacteria isolate efficated in shallot plants on lowland shows not-real effects toward the growth of shallot growth and production except in the parameter of plant height on lowland showing the treatment of isolate MK 11 that gives the best height of plant. Nevertheless, there seems to be a tendency of the promotion of shallot plant growth by giving the treatment of isolate MK 11 seen in other parameters, namely leaves number, bulb tillers number, weight of fresh residual bulbs and weight of dry residual bulbs.

\begin{tabular}{|c|c|c|c|}
\hline Isolate of Bacteria & Treatment & & $\mathbf{\alpha = 0 . 0 5}$ \\
\hline MK 11 & 29.60 & ${ }^{a}$ & 5.91 \\
\hline MK 6-1-1 & 28.00 & ${ }^{a}$ & \\
\hline LB 3 & 28.00 & ${ }^{a}$ & \\
\hline LB 8 & 19.20 & ${ }^{\text {b }}$ & \\
\hline LB 4 & 16.60 & ${ }^{b}$ & \\
\hline
\end{tabular}

Values followed by the same letters are not significantly different on degree 0.05 Table 2: Height of shallot plant 1 month after the planting.
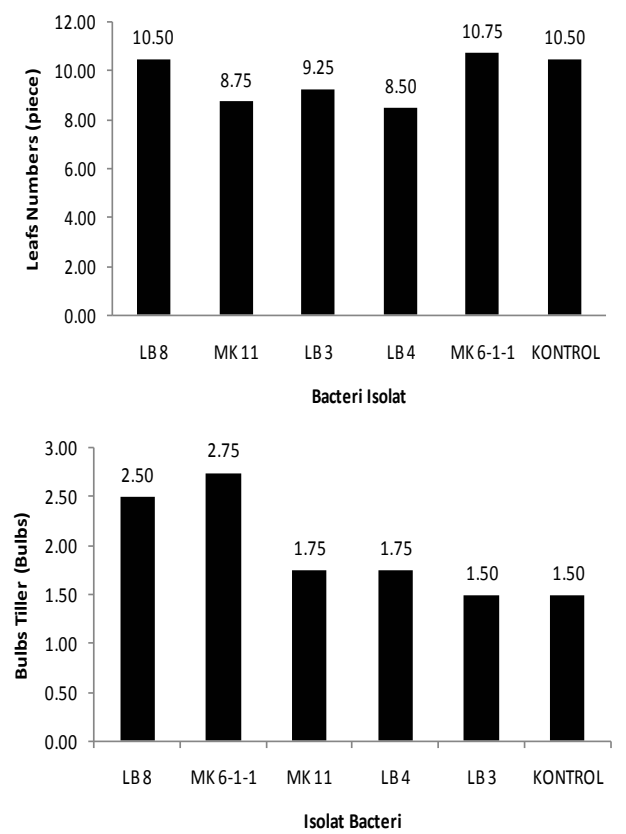

Figure 2: Leaves number of shallot bulb tillers 1 month after the planting.

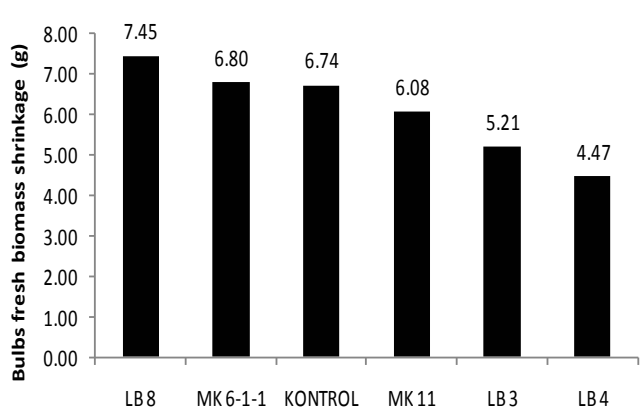

Isolat Bakteri

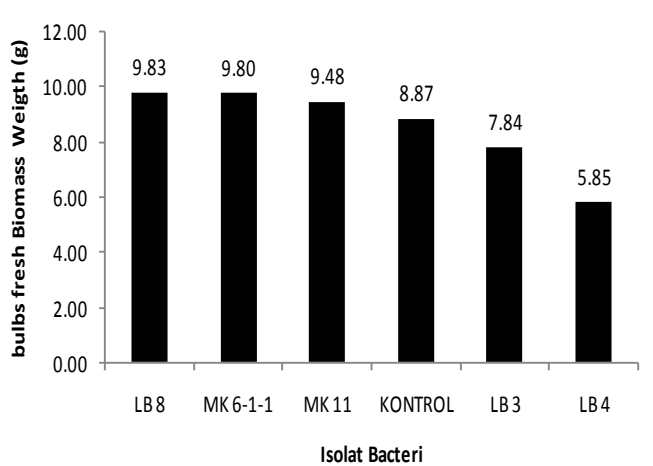

Figure 3: Weight of fresh residual bulbs and weight of dry residual bulbs of shrinkage shallot 1 month after the planting. 
Citation: Kafrawi, Nildayanti, Zahraeni K, Baharuddin (2017) Comparison of IAA Production by Shallot Rhizosphere Isolated Bacteria in Solid and Liquid Media and Their Effect on Shallot Plant Growth. J Microb Biochem Technol 9: 266-269. doi: 10.4172/1948-5948.1000375
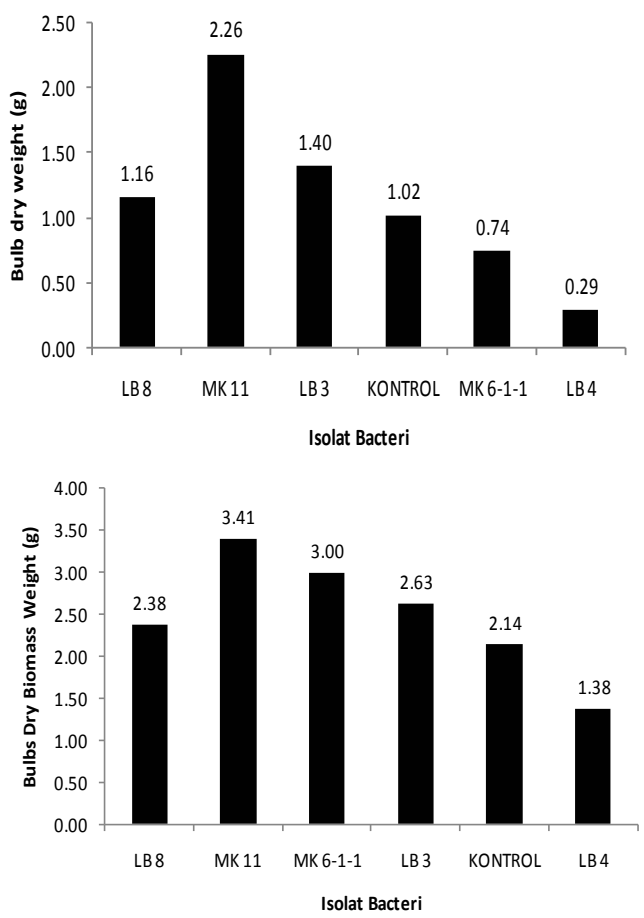

Figure 4: Weight of fresh residual bulbs and weight of dry residual bulbs of shrinkage shallot 1 month after the planting.

Results of test of auxin production of bacterial isolate MK 11 did show the highest production compared to other isolates, namely 2.33 $\mathrm{ppm}$. The highest concentration of auxin produced by isolate MK 11 enabled the giving of it to the planning medium more what can be absorbed by shallot plants so it can promote the growth of shallot plants and in the end encourage the increase of shallot plants production.

According to Wattimena [22], the increase of wet weight especially due to the increase of water taking by cells. Cells can develop in various ways. Some osmotic materials such as sugar can be transported to vacuole. Water will enter cells and cell walls and will develop until a certain cell wall pressure that can hinder the next water absorption. The cell walls cracked by this development are repaired with the addition of new cell wall materials. The role of auxin in this process is to change vacuole osmotic properties.

Bacteria isolate MK 6-1-1 is also fairly potential to promote shallot growth, its effect is more obvious in shallot plant that are grown on lowland especially in the parameter of leaves number and of bulb tillers. Overall, bacteria isolates in this experiment is worth developing to become a bacteria consortium useful to promote shallot growth because its treatment effect is not really different.

\section{Conclusion}

The isolate MK6-1-1 showed the best stimulatory effect on leaves number and bulb tillers, isolate LB8 was investigated to modulate better bulbs fresh biomass weight, while isolate MK11 was found to have the best effect on bulbs dry weight and bulbs dry biomass weight. Application of liquid media MK 6-1-1 bacteria isolates on the medium shallot planting early phases provides the best results on the vegetative growth of shallot that is leafs number (10.75 pieces) and the number of bulbs tillers ( 2.75 bulbs) except the best plants height showed by Isolate bacteria MK $11(29.60 \mathrm{~cm})$. Bacterial isolates LB 8 shows bulbs fresh biomass weight $(9.83 \mathrm{~g})$ and bulbs fresh biomass shrinkage (7.45) while the bacteria Isolate MK 11 showed the best result of bulb dry weight $(2.26 \mathrm{~g})$ and bulbs dry biomass weight (3.41).

\section{References}

1. Leveau JH, Lindow SE (2005) Utilization of the plant hormone indole-3-acetic acid for growth by Pseudomonas putida strain 1290. Appl Environ Microbio 71: 2365-2371.

2. Van Loon LC (2007) Plant responsesto plant growth-promoting rhizobacteria Eur J Plant Pathol 119: 243-254.

3. Torres-Rubio MG, Valencia-Plata SA, Bernal-Castillo J, Martínez-Nieto P (2000) Isolation of enterobacteria, Azotobacter sp. and Pseudomonas sp., producers of indole-3-acetic acid and siderophores, from Colombian rice rhizosphere. Rev Lat Am Microbiol 42: 171-176.

4. El-Mahrouk ME, Belal EBA (2007) Production of indole acetic acid (bioauxin) from Azotobacter sp. isolate its effect on callus induction of Diffenbachia maculate cv. marianne. Acta Biologica Szegediensis 51: 53-59.

5. Benizri E, Courtade A, Picard C, Gucker A (1998) Role of maize root exudates in the production of auxins by Pseudomonas flourescens M.3.1. Soil Biol Biochem 30: 1481-1484.

6. Patten CL, Glick BR (1996) Bacterial biosynthesis of indole-3-acetic acid. Can J Microbiol 42: 207-220.

7. Aryantha, I Nyoman P, Dian P, Lestari dan, Nurmi Puri Dwi P (2004) Potensi Isolat Bakteri Penghasil IAA dalam Peningkatan Pertumbuhan Kecambah Kacang Hijau pada Kondisi Hidroponik. Jurnal Mikrobiologi Indonesia 9: 43-46.

8. Raharjo BW (2004) Kajian Pemberian Sulfur dan Zat Pengatur Tumbuh IAA terhadap Hasil Bawang Merah (Allium ascalonicum L.). Tesis: Program Pascasarjana Universitas Sebelas Maret, Surakarta.

9. Kafrawi B, Enny L, Sengin, Ade R (2014) Screening of free-living indole acetic acid producing rhizobacteria from shallot rhizospheres in the island of Sulawesi. Intern J Scien Tech Res.

10. Zakry FAA, Halimi MS, Abdul Rahim KB, Osumanu HA, Wong SK, et al. (2010) Isolation and plant growth promoting properties of rhizobacterial diazotrophs from pepper vine. Malaysia Application Biology 39: 41-45.

11. Loper JE, Scroth MN (1986) Influence of bacterial sources on indole-3 acetic acid on root elongation of sugarbeet. Phytopathology 76: 386-389.

12. Pelczar MJ, Chan ECS (1986) Dasar Dasar Mikrobilogi 1, Penterjemah: Ratna Siri Hadioetomo dkk Universitas Indonesia Press, Jakarta.

13. Atlas RM (2004) Handbook of Microbiological Media fourth Edition Volume 1. United States Of America: CRC Press.

14. Cappuccino JC, Sherman N (1992) In: Microbiology: A laboratory Manual 3rd ed New York: Benjamin/Cumming Pub. Co.

15. Sokatch JR, Burns G (1984) Oxidation of glycine by Pseudomonas putida requires a specific lipoamide dehydrogenase. Arch Biochem Biophys 228: 660-666.

16. Gandjar I (2006) Mikologi Dasar dan Terapan. Jakarta :Yayasan Obor Indonesia

17. Madigan MT, David P, David S, John MM (2011) Brock microbiology of microorganisms. San Francisco: Benjamin Cummings publishing.

18. Husen E, Saraswati R (2003) Effect of IAA-producing bacteria on the growth of hot pepper. J Mikrobiol Indones 8: 22-26.

19. Sutariati GAK (2006) Perlakuan benih dengan agens biokontrol untuk pengendalian penyakit antraknosa, peningkatan hasil dan mutu benih cabai', Disertasi, Program Pascasarjana, Institut Pertanian Bogor, Bogor.

20. Wei G, Kloepper JW, Tuzun S (1996) Induced systemic resistance to cucumber diseases and increased plant growth by plant growth-promoting rhizobacteria under field conditions. Phytopathology 86: 221-224.

21. Thakuria D, Talukdar NC, Goswami C, Hazarika S, Boro RC, et al. (2004) Characterization and screening of bacteria from the rhizosphere of rice grown in acidic soils of Assam. Curr Sci 86: 978-985.

22. Wattimena (1988) Zat Pengatur Tumbuh. Antar Universitas IPB. Lembaga Sumber Daya Informasi, IPB. 